\title{
С.Ф. Пічугін
}

Національний університет «Полтавська політехніка імені Юрія Кондратюка», Україна

\section{РОЗВИТОК НОРМУВАННЯ КРАНОВИХ НАВАНТАЖЕНЬ НА БУ ДІВЕЛЬНІ КОНСТРУКЦІї}

Виконано систематизований огляд результатів досліджень і наукових публікацій з проблеми кранового навантаження за 90-річний період з 30-х років ХХ століття до теперішнього часу. Підкреслюється, щчо це навантаження на споруди має складну фізичну природу і мінливий характер. Головна увага приділяється аналізу еволючії норм проектування конструкцій в частині змін розрахункових коефіцієнтів, призначення нормативних і розрахункових значень кранового навантаження. Відзначається, щуо більшість параметрів норм кранового навантаження мають імовірнісну природу і вимагає для свого обтрунтування застосування статистичних методів. Виділяються наукові результати, що можуть бути включеними в наступні видання норм кранового навантаження.

Ключові слова: мостові крани, підвісні крани, кранове навантаження, нормативне навантаження, розрахункове навантаження.

\section{Постановка проблеми}

Підйомно-транспортні машини - незамінний елемент будь-якої сфери економіки. Технологічний процес більшості виробничих підприємств пов'язаний з необхідністю механізувати операції по вертикальному і горизонтальному транспортуванню вантажів з великим діапазоном ваги. Цю механізацію поряд 3 іншими транспортними засобами здійснюють за допомогою мостових (опорних) i підвісних кранів, що представляють собою спеціальні пристрої, які рухаються 3 вантажами уздовж і поперек цеху. Забезпечення надійності та безаварійності будівель і споруд у великій мірі залежить від правильного розуміння природи i кількісного опису та нормування навантажень на будівельні конструкції, в тому числі кранових навантажень. Навантаження від кранів можуть бути значними, вони мають змінний динамічний характер і здійснюють суттєвий силовий вплив на конструкції виробничих будівель. Ці особливості в певній мірі відображаються в розділах норм проектування будівельних конструкцій, що містять нормативи кранового навантаження. Більшість параметрів норм кранового навантаження має імовірнісну природу і вимагає для свого обгрунтування застосування статистичних методів. Ці методи постійно змінювалися i розвивалися разом регулярним переглядом норм будівельного проектування. Аналіз еволюції вітчизняних норм кранового навантаження разом 3 їх статистичним обгрунтуванням представляє собою актуальну задачу.

\section{Аналіз останніх досліджень і публікацій}

Iз затвердженням перших вітчизняних будівельних норм, що включали розділ кранових навантажень, зв' язані публікації 30 -х років будівельників і кранівників [1-3]. Згодом активні дослідження навантажень мостових кранів виконувалися у ЦНІПС [4, 5]. Цей процес активізувався 3 підготовкою розрахунків конструкцій на методику граничних станів [6]. У післявоєнні роки дослідження кранових навантажень відновив ЦНДІБК [7-10]. У 60-80-ті роки комплексні дослідження кранових навантажень виконувала Випробувальна станція Московського інженерно-будівельного інституту (МІБІ) [11-33]. Починаючи з 70-х років дослідження кранових навантажень проводяться у Полтавському інженерно-будівельному інституті (нині Національний університет «Полтавська політехніка імені Юрія Кондратюка») [34-44]. Проведені дослідження сприяли регулярному перегляду норм навантажень i вдосконаленню нормування кранових навантажень. Починаючи 3 90-х років минулого століття, норми проєктування розроблялися окремими країнами, що раніше входили у склад СРСР. У зв'язку з цим в Україні активізувалися імовірнісні дослідження кранових навантажень, результатом яких став відповідний розділ ДБН В.1.2-2006 «Навантаження і впливи». У наступні роки дослідження кранових навантажень продовжилися разом із обгрунтуванням і уточненням розрахункових коефіцієнтів норм проектування [45-48]. 


\section{Мета статті}

Метою роботи $\epsilon$ систематизований огляд результатів досліджень і наукових публікацій 3 проблеми кранових навантажень за 90-річний період 3 30-х років XX століття до теперішнього часу. Підкреслюється, що ці навантаження на споруди мають складну фізичну природу i мінливий характер. Головна увага приділяється виявленню зв'язку розвитку норм кранових навантажень 3 результатами експериментальних досліджень цих навантажень. Виділяються аспекти імовірнісного обгрунтування розрахункових коефіцієнтів, призначення нормативних і розрахункових значень кранового навантаження. Виділяються наукові результати, що можуть бути включеними в наступні видання норм кранового навантаження.

\section{Виклад основного матеріалу}

Початок вітчизняного нормування кранових навантажень було покладено в 1930 р., коли Комітет зі стандартизації при Раді Праці і Оборони підготував і ввів в дію перші норми в галузі будівництва «Сдині норми будівельного проектування». 3 огляду на те, що в той час відповідні експериментальні роботи в СРСР не проводилися, основу прийнятих нормативів становили зарубіжні норми, роботи кранівників та довідкові видання, наприклад [1]. У розвиток «Сдиних норм» були розроблені різні відомчі нормативні документи. Зокрема, були прийняті «Технічні умови і норми проектування металевих конструкцій» (1931 і 1934 рр.). У них горизонтальні навантаження, що передаються від кранів на кранові колії та спрямовані уздовж будівлі, визначалися як

$$
H=0,1 P n,
$$

де $P$ - розрахунковий вертикальний тиск на колесо крана; $n$ - кількість гальмівних коліс крану, що знаходиться на балці.

При цьому значення сил звичайної інтенсивності приймалися рівними 0,5 величин, отриманих за формулою (1) (очевидно, таким чином робилася перша спроба врахування режиму роботи мостових кранів). Формула (1) отримана на підставі закону тертя $F=f N$, тобто сила тертя $F_{\text {дорівнює }}$ нормальному тиску $N$, помноженому на коефіцієнт тертя між рейками і колесами крана $f$, рівний 0,1 . Висловлювалася думка, що цей коефіцієнт дещо занижений, так як, наприклад, для залізничних локомотивів коефіцієнт тертя між рейкою і колесом у звичайних умовах становив від $1 / 5$ до $1 / 6$.
Для особливо швидко або повільно працюючих кранів ТУ дозволяли визначати горизонтальні сили за формулою:

$$
H=\frac{\sum Q}{10} \cdot \frac{v}{t},
$$

де $\sum Q / 10$ - маса вантажів, що переміщаються (цифра 10 в знаменнику наближено враховує $g=9,8 \mathrm{M} / \mathrm{c} 2) ; \quad v$ - максимальна швидкість руху крана; $\boldsymbol{t}$ - час гальмування.

Формула (2) була отримана 3 умови рівності кінетичної енергії руху та роботи сили Н. При зростанні швидкості за законом трикутника ця формула визначає середню величину сили, що дорівнює половині максимальної миттєвої сили $H_{\max }$, що виявляється при гальмуванні.

У період 1930-1940 рр. спостерігався певний різнобій в проектно-будівельному нормуванні. Різні відомчі нормативи та технічні умови не завжди відповідали один одному. Відносно сил поперечного гальмування електричних кранів вказувалося, що вони розподіляються не на одну рейку, а на дві, пропорційно бічній жорсткості підкранових балок $[2,3]$.

В кінці 30-х років минулого століття провідна будівельна науково-дослідницька організація Центральний науковий інститут промислових споруд (ЦНІПС) - організувала масштабні натурні дослідження дійсної роботи і навантажень мостових кранів на сталеві каркаси виробничих будівель. Вивчення горизонтальних навантажень 60-тонного мостового крана мартенівського цеху провів інж. О.І. Кікін [4]. Експеримент підтвердив справедливість формули (2) при пуску і гальмуванні як самого крана, так і його візка. У наступних варіантах норм навантажень ця формула відсутня.

Співробітник ЦНІПС Н.С. Романов провів випробування 60, 125 і 220-тонних ливарних кранів [5]. Вимірювання при стоячому в створі випробувань крані з гальмуючим візком підтвердили справедливість формули (1) без введення понижуючого коефіцієнта 0,5. Поперечні навантаження при проїздах кранів повз створу вимірів мали різний характер, проте у всіх випадках вони значно перевищували сили від гальмування візка.

Розвиток методів розрахунку будівельних конструкцій, особливо для оцінювання запасу міцності конструкцій, вимагав об'єктивно виявляти параметри навантажень і міцності матеріалів [6]. Тому зросла необхідність використання статистичних методів для опису змінних навантажень, що мають виразний випадковий характер. Однак в цей 
період подібні методи не розроблялися, і рішення щодо перегляду норм кранових навантажень приймалися на основі досвіду експлуатації, без імовірнісного обгрунтування.

У 1940 р. був прийнятий стандарт ОСТ 9005740 «Навантаження корисні», в якому кранові навантаження були уточнені. На додаток до попередніх вимог в ньому підкреслювалося, що поперечна сила повинна залежати від типу підвісу вантажу. Для кранів 3 гнучким підвісом вантажу ця сила приймалася, як і раніше, рівною 0,05 суми вантажопідйомності і ваги візка, а для кранів 3 жорстким підвісом вдвічі більше - 0,1 тієї ж суми. На відміну від колишніх вимог в стандарті вказувалося, що поперечне гальмівне зусилля від крана слід передавати повністю на одну підкранових балку і розподіляти порівну між усіма колесами 3 цього боку крана. Таким чином, гальмівна сила, що передається на колесо крана 3 гнучким підвісом вантажу визначалася як

$$
T_{k}=\frac{0,05}{n_{0}}\left(Q_{t}+Q\right)
$$

де $Q_{t}$ - вага візка крана; $Q$ - вантажопідйомність

крана; $n_{0}$ - кількість коліс 3 кожного боку моста крана.

У 1942 р. замість ОСТ 90057-40 видається державний стандарт ГОСТ 1645-42. Додатково до попередніх вимог в ньому уточнюється, що при розрахунку підкранових конструкцій вертикальне навантаження приймається від фактичного числа кранів, але не більше ніж від двох кранів, що зближуються для спільної роботи в кожному прольоті будівлі i на кожному ярусі. В багатопрольотних цехах враховується можливість розташування кранів в одному створі в сусідніх прольотах.

У передвоєнні і перші повоєнні роки Інститутом Гіпромез під керівництвом к. т. н. O.I. Кікіна (згодом доктора технічних наук) виконувалися масштабні дослідження режиму експлуатації та навантажень мостових кранів в цехах металургійного виробництва. О.І. Кікін поділив горизонтальні поперечні впливи мостових кранів на бічні сили, що виникають при русі кранів по підкрановим коліям, і гальмівні сили, викликані гальмуванням візків мостових кранів. Величини бічних сил визначали наступні складові: рухомий момент від перекосу моста крана, розпір між краном і поперечною рамою цеху і сили розпирання або стягування, що виникають при звуженнях або розширеннях підкранових колій. Виміряні бічні сили були значно (до $3 . .5$ разів) більше навантажень від гальмування візків з вантажем.
На підставі виконаних експериментальнотеоретичних розробок були дані наступні рекомендації щодо розрахунку конструкцій на кранові навантаження:

a) розрахунок поперечних рам і колон допускається проводити за нормативною розрахунковою схемою 3 подальшим збільшенням моментів у верхніх частинах колон на $50 \%$; для випадку перекосу кранів (при $Q<30$ тс і $L_{c r} / B \geq 5$ ) рекомендується враховувати одну силу $H=G_{c r} L_{c r} / 100 B$ ( $Q$ - вантажопідйомність крана; $G_{c r}$ - загальна вага крана; $L_{c r}, B$ - проліт і база крана);

б) бічні сили необхідно розглядати як місцеве навантаження при розрахунку верхніх поясів підкранових балок, гальмових ферм і кріплень підкранових балок до колон, причому їх величини на колеса приймати рівними:

для кранів з гнучким підвісом - $H=0,1 F_{c e p}$; для кранів з жорстким підвісом - $H=0,1 F_{\max }$;

для кранів, схильних до перекосу $H=G_{c r} L_{c r} / 100 B-0,1 F_{\min }$.

Тут $F_{(.)}$- вертикальні тиски коліс кранів.

Отримані результати були використані при складанні ТУ 104-53 «Технічні умови проектування сталевих конструкцій будівель металургійних заводів 3 важким режимом роботи». У них були введені бічні сили, які, однак, рекомендувалося враховувати тільки для окремих конструкцій і вузлів шляхом множення нормативних гальмівних сил на підвищувальний коефіцієнт, що дорівнював 1,1...2,5, при розрахунку верхніх поясів підкранових балок і гальмівних конструкцій, i коефіцієнт, рівний $2,2 \ldots 5,0$, при розрахунку кріплення гальмівних конструкцій підкранових балках до колон. Такий підхід носив вимушений вибірковий характер і не брав до уваги бічні сили при розрахунку поперечних рам. Дані коефіцієнти потім перейшли в НіТУ 12155 «Норми і технічні умови проектування сталевих конструкцій». Крім того, вперше пророблялися розрахункові схеми завантаження вертикальним крановим навантаженням, що можна вважати першим підходом до вирішення завдання сполучення компонентів даного навантаження.

У 50-ті роки минулого століття дослідження бічних сил мостових кранів були продовжені в ЦНІПС під керівництвом М.Ф. Барштейна [7]. В якості нормативного навантаження було запропоновано прийняти бічні сили, що виникають при русі набігаючого на рейку крана 3 колесами, що мають нормальні заводські допуски, при підкранових шляхах, укладених зі звичайними монтажними відхиленнями. У цьому випадку формула бічних сил 
3 урахуванням псевдоковзання i кута перекосу колеса $\beta=0,001$ отримала такий вигляд:

$$
H=1,5 \sqrt{F_{\max } \cdot d} \text { (кгс), }
$$

де ${ }^{d}$ - діаметр колеса крана.

Величини, підраховані за формулою (4), виявилися близькими результатами, обчисленими за формулою $H=0,1 F_{\max }$, яку М.Ф. Барштейн рекомендував для визначення бічних сил.

Перше видання Державних будівельних норм і правил СНіП ІІ-Б.1-54 «Навантаження і впливи» зберегло загальні рекомендації попередніх нормативів щодо навантажень мостових кранів, зазначивши, що «... вплив перекосів крана повинен враховуватися відповідно до спеціальних норм і технічних умов». У зв'язку 3 переходом до методики розрахунку конструкцій за граничними станами для кранового навантаження був введений коефіцієнт перевантаження 1,3.

Роботи по вивченню бічних сил мостових кранів продовжилися, починаючи 31954 р., в Інституті ВНДІПТМАШ під керівництвом В.П. Балашова [8]. Дослідження включали теоретичну частину, експериментальну перевірку і стосувалися чотириколісних і багатоколісних кранів 3 колесами на підшипниках кочення 3 центральним і роздільним приводами. Розрахунковим випадком вважався перекіс крана при його русі, який викликають численні фактори, серед яких виділяється різниця діаметрів і перекіс осей коліс, а також зміщення кранових шляхів в горизонтальній і вертикальній площинах. Було встановлено, що джерелами виникнення бічних сил є сили тертя поперечного ковзання колеса, поперечні сили взаємодії реборди колеса і бічної поверхні рейок при їх контакті, поперечна складова сил опору руху. Експеримент показав, зокрема, що величини бічних сил при роздільному приводі були значно менше, ніж при центральному, i характер їх зміни був більш спокійним. У разі, коли реборди не торкалися рейок, на колесах діяли сили поперечного ковзання, величини яких становили в середньому 0,1 від вертикального тиску на колесо. Проведені роботи розвинули уявлення про механічну природу бічних кранових сил, проте виведені формули не були включені в норми через свою громіздкість.

Ряд експериментальних досліджень кранових навантажень був проведений в ЦНДІБК у 19541955 рр. під керівництвом А.Х. Хохаріна [9]. Експерименти ставилися на дослідному каркасі, обладнаному мостовим краном вантажопідйомністю 10 тс, а також в діючих цехах. Дослідження підтвердили, що в якості основного випадку силової взаємодії крана 3 підкрановими конструкціями слід розглядати випадок перекосу крана 3 контактом реборд колес. На підставі наведених експериментальних досліджень була запропонована розрахункова формула бічної сили, що передає колесо крана:

$$
T=\alpha \beta \frac{L_{c r}}{B} F_{\max }
$$

де $F_{\max }$ - максимальний вертикальний тиск колеса; $\beta$ - коефіцієнт, що враховує співвідношення жорсткості моста крана і поперечної жорсткості рами цеху; $\alpha$ - коефіцієнт, що приймається в залежності від вантажопідйомності крана і режиму роботи цеху в межах $0,01 \ldots 0,03$ для розрахунку гальмівних ферм і верхніх поясів підкранових балок i вдвічі більше - для розрахунку кріплень гальмівних ферм до підкранових балок і колон, рейок до підкранових балок.

В кінці 50-х років минулого століття вийшла перша публікація щодо статистичного дослідження кранових навантажень, в якій О.О. Бать (ЦНДІБК) навів результати натурних досліджень режиму навантаження підкранових балок [10]. Дослідження проводилися в 1956-1958 рр. в 25 діючих цехах 4 металургійних заводів, всього було зафіксовано більше 8 тис. циклів завантаження підкранових балок. Отримані дослідні статистичні дані по режиму експлуатації підкранових балок дозволили розвинути їх розрахунок на витривалість і дали уявлення про статистичну мінливість вертикальних кранових навантажень.

У 50-80-ті роки минулого століття вивчення навантажень мостових кранів активно проводилися в Московському інженерно-будівельному інституті (МІБІ) на Випробувальної станції кафедри металевих конструкцій. Результати цих досліджень узагальнені в колективних монографіях [11, 12], в написанні яких брав участь автор цієї статті. Перше масштабне статистичне вивчення вертикальних навантажень мостових кранів було проведено в кінці 50-х років минулого століття Б.М. Кошутіним [13]. Спостереження проводилися в 23 прольотах цехів різного призначення. Були отримані 52 експериментальних полігонів розподілу, що включали 65535 випадків появи вертикальних навантажень на колони і підкранові балки. Полігони виявилися симетричними, одновершинними і були обгрунтовано замінені кривими нормального закону. Розробляючи імовірнісний підхід до визначення коефіцієнта перевантаження, Б.М. Кошутін звернув увагу на хибне уявлення 50 -х років минулого століття, що розрахункове навантаження повинно знаходитися на відстані трьох або чотирьох стандартів від центру кривої розподілу, тобто ймовірність 
його перевищення не повинна бути більше 1,3·10-3 або 3,1·10-5. Якщо ж врахувати, що вертикальне кранове навантаження може діяти на колони, згідно 3 отриманими експериментальними даними, $\mathrm{N}=$ $(0,6 \ldots 6,5) 106$ разів за 20-річний термін експлуатації, то стає очевидним, що наведені вище ймовірності не забезпечують достатню забезпеченість нормування кранових навантажень. 3 огляду на це, було запропоновано такий вираз для коефіцієнта перевантаження

$$
n=\left[1,1(\bar{X}+\beta \hat{X})+0,1 \frac{F_{K}}{F_{M 1}}\right] \frac{F_{M !}}{F_{M 2}},
$$

де $\bar{X}$ i $\hat{X}$ - експериментальне середнє статистичне значення і стандарт; $F_{K}$ - навантаження на колону від ваги моста; $F_{M 1}$ і $F_{M 2}$ - навантаження на колону відповідно від одного і двох кранів; $\beta$ кількість стандартів, що відповідає ймовірності перевищення розрахункового навантаження $F_{R}$, $V\left(F \geq F_{R}\right)=1 / N$, де $\mathrm{N}-$ кількість завантажень за термін експлуатації.

На основі проведених статистичних досліджень були запропоновані диференційовані значення (прийняті з запасом) коефіцієнтів перевантаження вертикального кранового навантаження $1,0 \ldots 1,2$ залежно від відношення $F_{M 1} / F_{M 2}$ i параметра $\eta=Q /\left(Q_{t}+Q_{K}\right)$, де $Q$ - вантажопідйомність крана; $Q_{t}$ - вага візка; $Q_{K}$ - вага моста крана.

О.О. Бать і Б.М. Кошутін у 1958 р. провели спільне дослідження вертикальних кранових навантажень на заводі Дніпроспецсталь у складах заготовок готового прокату прокатного цеху i в розливному прольоті електросталеплавильного цеху [14]. Обидві методики дали наступні основні результати, що збігаються:

- криві розподілу вертикального навантаження на колони мають приблизно симетричний вид 3 найбільш імовірною величиною $0,35 \ldots 0,60$ від нормативного навантаження одного крана без динамічного коефіцієнта;

- випадки повного зближення двох кранів рідкісні і не надають помітного впливу на вигляд кривих розподілу навантажень;

- коефіцієнт перевантаження для кранового навантаження може бути знижений з 1,3 до 1,2.

У 1962 р. виходить друге видання СНиП II-А. 11-62 «Навантаження і впливи». В об'ємній публікації [15] укладачі норм перераховують нові моменти видання, що стосуються кранових навантажень. Зменшено значення коефіцієнта перевантаження 3 1,3 до 1,2 для вертикального i горизонтального навантажень від кранів вантажопідйомністю 5 тс і більше (чим враховані наведені вище результати статистичних досліджень). Даний варіант СНіП, як і раніше, дистанціювався від конкретики у визначенні бічних сил мостових кранів: «Горизонтальні поперечні навантаження, що виникають при русі крана внаслідок його перекосів і непараллельности підкранових колій слід визначати і враховувати в розрахунку відповідно до положень норм проектування будівельних конструкцій будівель і споруд різного призначення». Відповідно до даної установки, для сталевих конструкцій були збережені коефіцієнти $\alpha_{1} \alpha_{2}$, що враховують дію бічних сил на окремі конструкції та вузли.

Випробувальна станція МІБІ в ці ж роки активно вивчала бічні сили мостових кранів. Хронологічно першими тут були дослідження I.B. Ізосімова на Череповецькому металургійному заводі [16]. Досліджувалися чотириколісні крани на підшипниках кочення $з$ метою виявлення чинників, що впливають на бічні сили. 3'ясувалося, що зміна швидкостей руху моста кранів не впливає на величини бічних сил. Коли зміщення рейок перевершували суму вільних зазорів реборд, виникали бічні сили, що перевершували раніше заміряні в 1,8...2,2 рази. При русі потягу з двох зближених кранів спостерігалося збільшення бічних сил на 20...35\% у порівнянні 3 дослідними величинами для одного крана, не досягаючи розрахункового значення сил в середньому на 18\%. Збільшення коефіцієнта тертя на одному з рядів (посипання рейки піском) викликало збільшення бічних сил на цьому ряду в $1,55 . .2,46$ рази і на протилежному - в $1,12 \ldots 1,23$ рази. Відзначаючи численність факторів, що впливають на бічні сили, і труднощі їх врахування розрахунком, І.В. Ізосімов [16] вважав найбільш раціональним визначати бічну силу в функції тільки вертикального тиску на колесо:

$$
H_{k}=f_{p} F_{k},
$$

де $H_{k}$ і $F_{k}$ - відповідно бічне і вертикальне навантаження на колесо; $f_{p}-$ коефіцієнт пропорційності, названий «реалізованим коефіцієнтом тертя поперечного ковзання», який повинен визначатися за даними натурних випробувань.

Останній термін не можна визнати вдалим, оскільки $f_{p}$ по суті $\epsilon$ узагальненням, що встановлює зв'язок горизонтального і вертикального навантажень. Постановка завдання в такому вигляді надмірно спрощує проблему, роблячи в той же час 
складним призначення $f_{p}$. Експериментальні значення реалізованих коефіцієнтів тертя були зведені в графіки залежності їх від вертикального тиску на колесо і описані степеневими функціями. Отримані І.В. Ізосімовим емпіричні залежності для бічних сил не можна визнати достатньо обгрунтованими через недостатність вихідного статистичного матеріалу і знеособлення ряду факторів.

Більш поглиблені дослідження поперечних навантажень мостових кранів в натурних умовах були проведені А.В. Фігаровським (МІБІ, Випробувальна станція), з яким автор довго і плідно співпрацював у спільних роботах. В одному 3 цехів машинобудівного заводу були проведені в 1962 1963 pp. експериментальні дослідження силових впливів чотириколісного мостового крана середнього режиму 3 роздільним приводом, вантажопідйомністю $15 / 3$ тс [17, 18]. Виконувалися одночасні вимірювання вертикальних і горизонтальних кранових навантажень. Використана комплексна методика була істотним кроком вперед у порівнянні 3 дослідженнями кранових навантажень попередніх років, була унікальною за своєю складністю i ретельності підготовки та застосування.

Характер записів бічних сил і вертикальних тисків при заїздах крана в однакових умовах майже не змінювався, що підтверджує сталість чинників, що визначають величини цих навантажень. Випробуваний кран виявився не схильним до перекосу, тому основним фактором виникнення бічних сил при сталому русі крана були кути перекосу ходових коліс відносно осі рейки $\mathrm{i}$ в меншій мірі - перекіс всього моста в плані. Аналіз залежності між вертикальним і горизонтальним навантаженнями на колесо показав, що при відсутності контакту реборди колеса 3 рейкою, а також для ведених коліс експериментальне значення коефіцієнта пропорційності становить 0,1 , і ця залежність близька до прямої. Цей коефіцієнт помітно збільшується для ведучих коліс, для яких експериментальні значення лягають значно вище зазначеної прямої. Не випадково тому, що змащування бічних поверхонь рейки зменшувала бічні сили в середньому в $2 \ldots 2,5$ рази. При відсутності зазорів бічні сили на колесах, що проходять розширені або звужені ділянки шляху, різко зростають. Зіставлення дійсних величин бічних сил 3 гальмівними, обчисленими за СНіП, виявило значне перевищення перших у $3 . . .4$ рази.

На підставі проведених випробувань, виходячи з умов руху крана, А.В. Фігаровський вивів формулу величин найбільших бічних сил, що можуть виникати на колесах чотириколісних кранів:

$$
H_{\kappa}=0,1 F_{\text {max }}+\alpha\left(F_{\text {max }}-F_{\text {min }}\right) \frac{L_{c r}}{B},
$$

де $F_{\max }$ i $F_{\min }$ - середні тиски коліс відповідно більш і менш завантаженого боку крана; $\alpha$ коефіцієнт, рівний 0,01 для кранів 3 роздільним приводом механізму руху і 0,03 - для кранів 3 центральним приводом.

У наведеній формулі перший доданок дає поперечну силу від перекосу колеса, другий горизонтальну складову на реборді колеса, що обмежує перекіс моста. На інших колесах можуть діяти тільки сили тертя, приблизно рівні $0,1 F$. Дана формула забезпечує досить близький збіг 3 експериментальними величинами.

А.В. Фігаровський провів також комплексний натурний експеримент в розливному прольоті мартенівського цеху металургійного заводу [19]. Випробовувався багатоколісний ливарний кран вантажопідйомністю 175 тс 3 центральним приводом. На відміну від чотириколісного крана, багатоколісний кран менш схильний до перекосів і має тенденцію зберігати постійним початковий кут перекосу. Це є наслідком менших відносин прольоту крана до його бази і наявності на кожній стороні моста балансирних візків, що допускають деякий поворот у вертикальній площині. Змащування бічної поверхні головки рейки істотно (в 1,7...2,0 рази) знизило величини бічних сил й їх динаміку на ділянках 3 нормальною колією. На величини i характер зміни бічних сил багатоколісних кранів істотно впливають відхилення ширини колії, що перевершують сумарні зазори реборд. Було виявлено, що в місцях звуження i розширення шляхів бічні сили зростають в 2,0...2,5 рази.

У 1963-1965 pp. в лабораторії динаміки ЦНДІБК поновилися дослідження бічних сил, які виконав А.Н. Зубков під керівництвом М.Ф. Барштейна [20]. В основу теоретичної розробки питання було покладено уявлення про рух мостового крана по підкранових шляху, що має випадкові відхилення в горизонтальній площині. Розглядався безперервний контакт рейки 3 ребордою одного колеса або 3 ребордами двох коліс, розташованих на одній кінцевій балці. Складалися диференціальні рівняння руху крана, причому вважалося, що відхилення шляхів в горизонтальній площині є стаціонарним нормальним процесом, кореляційні функції якого обчислювалися за матеріалами геодезичної зйомки підкранових колій в діючих цехах. На підставі проведених досліджень була запропонована формула для визначення розрахункових величин 
поперечних сил, що діють на колесах крана при обмеженні перекосу ребордами коліс одного боку крана:

$$
R=15\left(\alpha \frac{L_{c r}}{b} \pm \beta\right) \sqrt{F} \quad \text { (в кгс), }
$$

де $L_{c r}$ - проліт крана; b - відстань між крайніми колесами крана; $F$ - середній вертикальний тиск колеса; $\alpha, \beta$ - коефіцієнти, що приймаються для чотириколісного, восьмиколісного і шестнадцятиколісного кранів рівними $\alpha=[0,4,0,8,1,6]$ і $\beta=$ $[1,3,7]$.

У ці ж роки на Випробувальній станції МІБІ розгорнулися імовірнісні дослідження навантажень мостових кранів. Перша спроба отримання i оброблення статистичних даних по горизонтальних навантаженнях мостових кранів була зроблена Б.М. Кошутіним в мартенівському цеху Череповецького металургійного заводу [21]. Були записані бічні сили на колони в умовах нормальної експлуатації цеху в розливному і пічному прольотах. Експериментальні величини коефіцієнта перевантаження мали великий розкид, причому для пічного прольоту перевищували нормативне значення, рівне 1,2 (згідно дійсного на момент випробувань варіанту СНiП).

У 1964-1966 рр. Пічугін С.Ф. провів комплексні натурні дослідження вертикальних і горизонтальних навантажень мостових кранів різного призначення $[17,19,22]$. Статистичний матеріал був зібраний в результаті безперервної реєстрації (протягом $3 . .18$ діб) кранових навантажень нормальної експлуатації в діючих цехах. Кранові навантаження представлялися у вигляді випадкових величин, були побудовані дослідні полігони навантажень, визначено їх числові характеристики та розроблено спосіб побудови розподілів поперечних сил по величинам навантажень при окремих операціях кранів. Були виявлені наступні особливості статистичних розподілів кранових навантажень:

- швидка стабілізація, тобто виявлення цих розподілів при врахуванні порівняно невеликого обсягу статистичного матеріалу, подальше збільшення якого не змінює картину ні якісно, ні кількісно;

- обгрунтована можливість застосування нормального закону для опису розподілів ординати вертикального і горизонтального кранового навантаження;

- тісний зв'язок роботи кранів та кранових навантажень 3 технологією виробництва цехів, в яких експлуатуються крани, стабільність траєкторій руху кранів та візків, вплив технологічних особливостей на імовірнісні характеристики кранових навантажень (фактичне розміщення зон роботи кранів, неоднакове завантаження конструкцій різних рядів, обмеження наближення візків кранів );

- специфічна особливість навантажень деяких кранів 3 гнучким підвісом (наприклад, ливарних), яка полягає у виділенні в їх розподілах крайніх «Хвостових» частин, що відповідають операціям 3 вантажами, близькими до вантажопідйомності; ці частини слід розглядати окремо [23].

На підставі аналізу статистичних розподілів поперечних навантажень кранів різного призначення для 14 прольотів 12 цехів трьох металургійних заводів були запропоновані формули для визначення нормативних значень цих навантажень (за узагальненими максимальними експериментальними величинами, збільшеними на 10\%):

1) для кранів 3 жорстким підвісом вантажу $H=0,25 F_{c p}^{\sigma c} \sum Y$;

2) для багатоколісних кранів 3 гнучким підвісом вантажу:

- на ділянках 3 нормальною колією

$H=0,15 F_{c p}^{\sigma z} \sum Y$;

- на ділянках зі звуженнями і розширеннями $H=0,25 F_{c p}^{6 z} \sum Y$;

3) для чотириколісних кранів 3 гнучким підвісом вантажу - величини визначаються за формулою А.В. Фігаровського (8).

Тут $\sum Y$ - відповідна сума ординат лінії впливу при врахуванні одного крана; $F_{c p}^{\text {бг }}$ вертикальний тиск колеса крана без вантажу 3 візком, розташованої посередині моста крана; вибір цієї величини обгрунтований важливістю даного параметра в формуванні статистичних розподілів поперечних сил і розподілі їх на групи.

При визначенні коефіцієнтів перевантаження кранового навантаження було враховано, що методи, засновані на продовженні і обриві кривих розподілу, мають ряд принципових недоліків. Тому був вибраний i успішно застосований для опису максимумів кранового навантаження подвійний експоненційний розподіл, поширений в статистиці екстремальних значень. Апроксимація експериментальних даних цим законом дала наступні коефіцієнти перевантаження бічних сил мостових кранів:

1) для кранів 3 жорстким підвісом вантажу $n=1,30$.

2) для багатоколісних кранів 3 гнучким підвісом:

- на ділянках звужень і розширень $n=1,15$;

• на ділянках з нормальною колією $n=1,30$. 
Випробувальна станція МІБІ (Ю.С. Кунін) в 1967-1968 рр. провела масштабні натурні вимірювання кранових навантажень в цехах металургійних заводів. Основні результати даної роботи викладені в об'ємній публікації [25], яка ілюструє перехід від представлення кранових навантажень у вигляді випадкових величин до ймовірнісної моделі випадкових процесів. Підтвердилося, що кранові навантаження - нормальні стаціонарні випадкові процеси, що мають ергодичний характер. Складена таблиця, в якій для вертикальних кранових навантажень 16 прольотів наведені значення математичного очікування $\bar{X}$, стандарту $\hat{X}$, коефіцієнта варіації $V_{x}$; частотної характеристики середнього числа $\bar{n}_{0}$ перевищень середнього рівня в одиницю часу. Отримані статистичні дані дозволили оцінити коефіцієнт перевантаження вертикальної кранового навантаження на основі теорії викидів випадкових процесів

$$
n=\bar{X}+\gamma \hat{X}
$$

де $\gamma$ - кількість стандартів, яке визначається 3 урахуванням прийнятого терміну служби конструкції і заданої ймовірності неперевищення $[P(T)]$ або перевищення $[Q]$ розрахункового значення кранового навантаження:

$$
\gamma(T)=\sqrt{2 \ln \frac{T \cdot \bar{n}_{0}}{-\ln [P(T)]}}=\sqrt{2 \ln \frac{\omega T}{2 \pi[Q(T)]}} .
$$

Тут у правій частині наведено варіант формули, в якому в якості частотної характеристики входить ефективна частота $\omega$ кранового навантаження - цей варіант використовувався в подальших дослідженнях кранових навантажень.

За формулою (11) був отриманий коефіцієнт перевантаження для терміну служби $\mathrm{T}=50$ років та ймовірності безвідмовної роботи $[P(T)]=0,999-$ $n=0,45 \ldots 1,08$, який в усіх випадках виявилися менше нормативного $n=1,2$.

Експлуатаційники і дослідники, у тому числі згадані вище, неодноразово відзначали, що фактичні вертикальні тиски на окремі колеса мостових кранів можуть істотно відрізнятися від паспортних значень. Такі відмінності прийнято називати «нерівномірністю тисків коліс кранів». Відомо, що мостовий кран являє собою статично невизначену просторову систему, що має в вертикальному напрямку досить велику жорсткість. Тому, наприклад, реальний 4-х колісний кран під час руху по реальним шляхах в окремі моменти може спиратися на рейки в трьох і навіть в двох точках (розташованих по діагоналі моста). Внаслідок цього навантаження на колеса мостових кранів можуть змінюватися як у бік збільшення, так і зменшення. Нерівномірність тисків коліс була детально досліджена В.Н. Валем (МІБІ, 1966-1969 рр.) [26], який застосував методику зважування в випробуваннях 26 кранів вантажопідйомністю 5...225 тс. Він запропонував враховувати збільшення тиску колеса мостового крана коефіцієнтом нерівномірності

$$
n_{H}=1+\Delta F / F_{n}
$$

де $\Delta F$ - збільшення тиску колеса; $F_{n}$ максимальний нормативний тиск колеса.

Випробування 3 підйомом коліс кранів на різну висоту дозволили виявити практично лінійну залежність тиску від згинально-крутильної характеристики моста крана і величини зазору між колесом i рейкою, названого реалізованим зазором. Причинами виникнення цього зазору при русі крана $€$ можливий перекіс конструкції крана, допущений при його виготовленні і монтажі, прогини підкранових балок, деформації колон i фундаментів i, головним чином, - нерівності кранових шляхів, масові в реальних умовах експлуатації. На підставі виконаних досліджень були отримані значення коефіцієнта нерівномірності тисків на окремі колеса кранів в діапазоні $n_{H}=1,3 \ldots 1,1$ для кранів вантажопідйомністю 5...200 тс.

Ще одним джерелом збільшення тиску окремих коліс крана $€$ їх динамічний характер, що враховується місцевим динамічним коефіцієнтом $k_{d, l o c}$, що залежить від жорсткості підкранових балок, швидкості руху кранів і особливо - від стану кранових шляхів. Експериментально отримані значення $k_{d, l o c}=1,0 \ldots 1,5$ залежать від типу підвісу вантажу і вантажопідйомності кранів.

Зі сказаного ясно, що фізична природа коефіцієнта $\gamma_{f 1}$ визначається взагалі нерівномірністю і динамічністю тисків окремих коліс, внаслідок чого цей коефіцієнт можна представити як добуток відповідних коефіцієнтів:

$$
\gamma_{f 1}=n_{H} k_{d, l o c}
$$

Беручи до уваги наведені вище значення коефіцієнта нерівномірності тиску на колесо $n_{H}$ i місцевого динамічного коефіцієнта $\mathrm{kd}, \mathrm{loc}$, В.Н. Валь вніс пропозицію (поки нереалізовану) 
збільшити даний коефіцієнт до наступних значень:

$\gamma_{f 1}=1,8-$ для кранів 3 жорстким підвісом; $\gamma_{f 1}=$ 1,5 для кранів з гнучким підвісом важкого режиму

роботи (групи режимів $7 \mathrm{~K}$ і $8 \mathrm{~K}) ;^{\gamma_{f 1}}=1,3$ - для інших кранів [26]. У зв'язку з викладеним можна вважати дещо заниженими, у порівнянні 3 фактичними, значення коефіцієнта $\gamma_{f 1}$, що містяться в нормах СНІП, i, відповідно, розрахункові величини місцевих напружень бloc,y у стінках підкранових балок. Такий стан є однією 3 причин високої пошкоджуваності верхньої зони підкранових конструкцій.

Наступним етапом статистичних досліджень Випробувальної станції МІБІ було вивчення в 19701973 рр. А.Т. Яковенко сполучень вертикальних кранових навантажень [27]. Статистичні дані були отримані для вертикальних навантажень 17 кранів, які працювали в 5 прольотах складів готової продукції і становому прольоті прокатних цехів, а також в двох прольотах (пічному і розливному) електросталеплавильного цеху двох металургійних заводів. Основним завданням роботи було дослідження коефіцієнтів сполучень зусиль в підкранових балках і колонах крайніх рядів, що враховують спільну роботу кранів у вивчених прольотах. Фактичні коефіцієнти сполучень кранових навантажень визначалися за формулою, придатною для будь-яких випадкових навантажень:

$$
\psi=\left[S_{\Sigma}\right] / \sum_{i=1}^{n}\left[S_{i}\right]
$$

де $\sum_{i=1}^{n}\left[S_{i}\right]$ - сума навантажень (зусиль) при невигідному завантаженні лінії впливу зближеними кранами за умови, що тиски окремих колес кожного крана можуть бути перевищені з ймовірністю $Q(t)$; $\left[S_{\Sigma}\right]$ - розрахункове навантаження (зусилля) при врахуванні фактичного випадкового процесу кранового навантаження, що визначається з умови тієї ж ймовірності перевищення за термін експлуатації $Q(t)$ за формулами (10) і (11).

Коефіцієнти сполучень за формулою (14) визначалися 3 ймовірністю $P(t)=1-Q(t)=0,95$ за термін експлуатації $\mathrm{t}=20$ років. 3 отриманих таким чином коефіцієнтів сполучень найбільшими виявилися експериментальні значення для кранів груп режимів $8 \mathrm{~K}(\psi=0,75 \ldots 0.85)$, які регулярно піднімають вантажі, близькі до номінальних, i мають великі швидкості руху. Дещо меншими, в межах $\psi=0,58 \ldots 0,73, \quad$ отримані коефіцієнти сполучень для кранів груп режимів 7К. Найменші значення $\psi=0,38 \ldots 0,40$ відзначені у кранів груп режимів 4К...6К. Ці крани менше завантажені, рідко піднімають вантажі, близькі до номінальних, зближуються відносно рідко. На основі проведених досліджень А.Т. Яковенко рекомендував, з урахуванням ймовірності безпечної роботи і терміну експлуатації, такі значення коефіцієнтів сполучень вертикальної кранового навантаження: $\psi=0,9$ для зони впливу 6 м і $\psi=0,8$ _ для зони впливу 12 м і більше.

У 1974 р. виходить чергове видання СНіП II-6-74 «Навантаження і впливи», в якому норми навантажень мостових кранів були об'єднані 3 нормами на навантаження від підвісних кранів. До тривалих навантажень (без експериментального обгрунтування) було віднесено навантаження від одного крана, помножене на 0,6 для кранів середнього режиму роботи i на 0,8 для кранів важкого i дуже важкого режимів роботи. 3 урахуванням масштабних досліджень кранових навантажень, проведених в 60-70-ті роки в МІБІ (про що описано вище), коефіцієнт перевантаження для навантажень всіх кранів був прийнятий рівним 1,2. Вперше була включена шкала понижуючих коефіцієнтів сполучення для вертикальних навантажень від двох і чотирьох кранів в межах $0,70 \ldots 0,95$ в залежності від режимів роботи кранів. Був введений норматив бічної сили, рівний для кожного ходового колеса 0,1 нормативного вертикального навантаження на колесо. Проте, як i раніше, непослідовно регламентувалося, що «... це навантаження повинно враховуватися при розрахунку тільки балок кранових колій i ï кріплень до колон в будівлях 3 кранами дуже важкого режиму роботи, 3 ливарними й іншими кранами важкого режиму роботи металургійного виробництва». Вперше для розрахунку на витривалість балок підкранових колій вказувалося, що нормативне навантаження від одного крана повинно множитися на коефіцієнт 0,6 для кранів середнього режиму роботи i на коефіцієнт 0,8 для кранів важкого і дуже важкого режимів роботи.

У 70-і роки в Дніпропетровському інституті інженерів залізничного транспорту (ДІІТ, Ю.А. Зданевич [28]) тривали розпочаті раніше рядом дослідників дослідження 3 оцінювання впливу на кранові навантаження особливостей технологічного процесу. Була обгрунтована рекомендація по зниженню коефіцієнта перевантаження до $\mathrm{n}=1,1$ для корисного вантажу сталерозливних ковшів (3 урахуванням зносу футеровки) при визначенні вертикальних навантажень ливарних кранів. Для мартенівського цеху з 10 
печами ємністю $220 . .450$ т були обгрунтовані наступні коефіцієнти сполучення для розрахунку вертикальних кранових навантажень в інтервалі $\psi=0,70 \ldots 0,90$

В цей же період особливості технологічного процесу прокатних цехів були виявлені також С.А. Нищетой (Випробувальна станція МІБІ) при проведенні експериментальних досліджень на семи мостових кранах важкого режиму роботи вантажопідйомністю $10 \ldots 20$ тс з гнучким підвісом траверси і роздільним приводом [29]. Отримані експериментальні статистичні дані, разом 3 результатами попередніх досліджень [12, 25], а також положеннями норм проектування мостових кранів [30], дозволили рекомендувати знизити коефіцієнт перевантаження кранового навантаження до $\mathrm{n}=1,1$.

Були отримані максимальні значення горизонтальних навантажень, які перевищували гальмівні сили в 2,5...3,0 рази. На підставі цих даних була запропонована наступна формула бічної сили на колесі крана з роздільним приводом:

$$
H_{k}^{n}=0,04 \frac{L_{c r}}{B} F_{\max }^{n},
$$

С.А. Нищета виконав також дослідження коефіцієнтів сполучень зусиль від вертикальних кранових навантажень для підкранових балок i колон крайніх і середніх рядів методом статистичного моделювання (Монте-Карло). Коефіцієнти сполучень вертикальних кранових впливів на колони від двох мостових кранів, розташованих на одному крановому шляху, і чотирьох кранів - на різних шляхах, визначалися за формулою

$$
\psi=S /\left(n S_{i}^{n}\right)
$$

де $\mathrm{S}$ - значення вертикальних навантажень на колону від двох або чотирьох мостових кранів, відповідне ймовірності реалізації $\mathrm{P}=0,95$ за час $\mathrm{T}=40$ років; $n S_{i}^{n}$ - сума добутків навантажень на колону від кожного 3 «k» коліс кранів (при невигідному завантаженні лініі впливу опорних реакцій підкранових балок) на відповідні фактичні значення (для кожного 3 прольотів) коефіцієнтів перевантаження $\mathrm{n}$.

Було виявлено, що коефіцієнти сполучень істотно залежать від довжини лінії впливу відповідного зусилля і відношення прольоту крана до його бази. Відзначено також залежність $\psi$ від протяжності робочої зони і від положення конструкції (колони, підкранової балки). Фактичні коефіцієнти сполучень, отримані в діапазоні $\psi=0,60 \ldots 0,95$, виявилися нижче (особливо при врахуванні чотирьох кранів), ніж встановлені в СНiП, що вказує, що в умовах експлуатації максимальні зближення двох (i тим більше чотирьох) кранів 3 граничним навантаженням явище виняткове. Тому була (i зараз є) можливість диференціації та подальшого зниження коефіцієнтів сполучень кранових навантажень.

У наступні роки у СНiП II-6-74 в частині кранових навантажень вносився ряд змін [31], які були включені у норми СНіП 2.01.07-85 «Навантаження і впливи», що вийшли через 11 років На основі статистичних даних, отриманих О.О. Батем, були знижені тривалі частини навантажень від мостових і підвісних кранів: з 0,6 до 0,5 від одного крана середнього режиму і з 0,8 до 0,7 - від крана важкого та дуже важкого режиму. Було вказано, що замість врахування двох кранів перевірка прогинів балок кранових колій повинна виконуватися від одного крана - на підставі досліджень М.Я. Кузіна (МІБІ [32]). Коефіцієнт надійності за навантаженням (який замінив колишній коефіцієнт перевантаження) за надійністю для кранових навантажень став прийматися рівним $\gamma_{f}=1,10$ (обгрунтування наводиться вище). Було внесено давно назріле доповнення - коефіцієнт збільшення зосередженого навантаження на окреме колесо мостового крана перенесений зі СНіП по сталевим конструкціям у

СНіП по навантаженнях в діапазоні ${ }^{\gamma_{f 1}}=1,10 \ldots 1,60$ в залежності від груп режимів роботи кранів i підвісу вантажу. Була дещо змінена сфера застосування нормативу бічної сили, яка спричиняється перекосами мостових кранів i непаралельністю кранових шляхів - тепер вона відносилася до розрахунку міцності і стійкості балок кранових колій й їх кріплень до колон в будівлях з кранами груп режимів роботи 7К, 8К. Таким чином, в нормах зберігся двоїстий підхід до нормування горизонтальних поперечних навантажень мостових кранів (гальмівні сили для звичайних кранів і бічні сили для кранів важких груп режимів роботи).

Останні за часом натурні випробування, націлені на комплексне вивчення кранових навантажень, були проведені В.А. Плотніковим в 90-і роки ХХ-го століття в цехах Магнітогорського металургійного комбінату [33]. Експериментальні величини поперечних сил від багатоколісних кранів у всіх випадках не перевищили нормативні значення за СНІП 2.01.07-85. Ця робота суттєво поповнила уявлення про характер і величини поперечних сил багатоколісних кранів. Однак у запропонованих формулах залишилися не визначеними імовірнісні 
коефіцієнти, не було виконано порівняння отриманих теоретичних формул 3 експериментальними даними.

Дослідження горизонтальних навантажень чотириколісних кранів В.А. Плотніков виконав на відкритій скрапоразделочній естакаді. Було виявлено, що величини експериментальних навантажень досить близько відповідають значенням, визначеним за формулою (15), запропонованої С.А. Нищетою для мостових кранів промислових будівель.

Дослідники, проектувальники і експлуатаційники виявили істотні недоліки СНіП 2.01.07-85 в частині нормування кранових навантажень.

1. Подвійний підхід до визначення горизонтальних поперечних впливів мостових і підвісних кранів. 3 одного боку, при розрахунку поперечних рам будівель і балок кранових колій пропонується враховувати навантаження, що викликається гальмуванням візка - поперечну гальмівну силу. 3 іншого боку, при розрахунку міцності і стійкості балок кранових колій i ïх кріплень до колон в будівлях 3 кранами груп режимів роботи 7 К, $8 \mathrm{~K}$ пропонується враховувати значно більші бічні сили, що спрямовані поперек кранового шляху i викликаються перекосами мостових електричних кранів і непаралельністю кранових шляхів.

2. Відсутність явного зв'язку нормативу кранового навантаження 3 періодом його повторюваності, що не дає можливості враховувати термін експлуатації будівель.

3. Недоліки в нормуванні зниженої складової кранового навантаження, що відноситься до тривалих навантажень і призначена також для розрахунку конструкцій на витривалість.

3 розпадом СРСР перед новими державами відкрилася можливість відійти від огрубленого радянського нормування і розробити власні, більш адекватні норми кранових навантажень. Подальший розвиток кранових норм на території СНД реалізувався у вигляді національних норм окремих держав.

Росія пішла шляхом поступового розвитку норм СНіП. Були розроблені Звід правил СП 20.13330.2011 «Навантаження і впливи» і актуалізована версія СНіП 2.01.07-85*. Вони не відрізняються принципово від попереднього варіанту СНіП 2.01.07-85 і включають такі зміни:

- для визначення бічних сил множник 0,1 замінений на 0,2 ;

- коефіцієнт надійності за навантаженням збільшений до $\gamma_{f}=1,2$ для кранів всіх груп режимів роботи;

- збільшений коефіцієнт, що враховує місцеву і динамічну дію вертикального навантаження від одного колеса крана, до $\gamma_{f}=1,2 \ldots 1,8 \quad$ (у відповідності з наведеними вище рекомендаціями В.Н. Валя).

Українські фахівці, на відміну від російських розробників норм, підготували Державні норми України ДБН В.1.2:2006 «Навантаження і впливи», концептуально відмінні від СНіП в частині кранових навантажень. Виходу у світ цих норм передувала систематизація результатів багаторічних робіт в області кранових навантажень, описаних вище, об'єднаними зусиллями співробітників МІБІ (Б.М. Кошутін, Ю.С. Кунин) і ПолтББ (нині Національного університету «Полтавська політехніка імені Юрія Кондратюка», В.А. Пашинський, С.Ф. Пічугін) [34, 35]. Були узагальнені 83 процеси кранового навантаження, 3 яких 8 відносилися до кранів 3 жорстким підвісом вантажу, а решта - до кранів 3 гнучким підвісом вантажопідйомністю $5 . .650$ тс різних груп режимів роботи. В результаті була створена узагальнена імовірнісна модель вертикального кранового навантаження у вигляді нормального стаціонарного випадкового процесу. Визначені 3 необхідною забезпеченістю математичне очікування $\bar{X}$, стандарт $\hat{X}$ і ефективна частота $\omega$ повністю описали вказаний випадковий процес. Були розроблені також такі математичні моделі кранових навантажень, як абсолютні максимуми випадкових процесів, схема незалежних випробувань, дискретне представлення, екстремуми, корельована випадкова послідовність перевантажень [36]. Це дозволило розвинути питання сполучення випадкових навантажень, в тому числі за участю кранових навантажень [37-39].

Норми ДБН В.1.2-2: 2006 по навантаженнях, включаючи кранові навантаження, концептуально побудовані аналогічно європейським нормам Eurocode [40]. У них основою для призначення навантажень $€$ характеристичні значення (раніше вони називалися нормативними). Розрахункові значення навантажень визначаються множенням характеристичних значень на коефіцієнт надійності за навантаженням $\gamma_{f i}$, який залежить від виду навантаження. ДБН розглядають кранове навантаження як змінне навантаження 3 чотирма розрахунковими значеннями вертикальної складової: граничним $F_{m}$, експлуатаційним $F_{e}$, циклічним $F_{c}$ і квазіпостійним $F_{p}[41,42]$ :

$$
\begin{aligned}
& F_{m}=\gamma_{f m} \psi F_{0} ; F_{e}=\gamma_{f e} F_{01} ; \\
& F_{c}=\gamma_{f c} F_{01} ; F_{p}=\gamma_{f p} F_{01},
\end{aligned}
$$

де $F_{01}, F_{0}$ - характеристичні значення вертикального навантаження відповідно від одного або двох найбільш несприятливих за впливом кранів 
(визначаються аналогічно нормативним навантаженням за СНіП); $\psi_{-}$коефіцієнт сполучень кранових навантажень, який перейшов в діапазоні 0,70...0,95 з попередніх норм.

Коефіцієнт надійності за граничним розрахунковим значенням кранового навантаження $\gamma \mathrm{fm}$ визначався, відповідно до загальної концепції ДБН, в залежності від середнього періоду повторюваності навантаження Т. Його максимальне значення було прийнято рівним $\gamma_{f m}=1,1$ на основі статистичних результатів ряду дослідників, які розглянуті вище. Цей коефіцієнт відповідає базовому періоду повторюваності навантаження $\mathrm{T}=50$ років $\mathrm{i}$ не змінюється при збільшенні Т внаслідок малої мінливості максимумів кранового навантаження. Для об'єктів 3 терміном служби менше 50 років можуть застосовуватися знижені коефіцієнти надійності в межах $0,97 \ldots 1,10$, визначені за формулою

$$
\gamma_{f m}(T)=\frac{1+V \gamma(T)}{1+V \gamma(T=50 \text { років })}
$$

де $V=\hat{X} / \bar{X} \quad$ - коефіцієнт варіації кранового навантаження; $\gamma(T)$ - нормоване відхилення від математичного очікування граничного розрахункового значення кранового навантаження при заданій ймовірності його перевищення $\mathrm{Q}(\mathrm{T})$, визначене за формулою (11).

Коефіцієнт надійності за експлуатаційним розрахунковим значенням кранового навантаження був прийнятий рівним $\gamma_{f e}=1$. Таким чином, для розрахунків конструкцій за другим граничним станом (прогини, переміщення і т.п.), використовується характеристичне навантаження від одного крана, на основі досвіду експлуатації, який показав обгрунтованість такого нормативу СНіП.

Циклічне розрахункове значення вертикального кранового навантаження, яке використовується в розрахунках підкранових конструкцій на витривалість, було включено в ДБН за пропозицією В.А. Пашинського [43]. Оскільки реальні процеси кранових навантажень $є$ випадковими і тому не можуть безпосередньо входити в розрахунки на витривалість, циклічне розрахункове значення визначається на основі схематизованого процесу навантаження найпростішого виду - гармонійного процесу із заданою частотою, еквівалентного за результуючою дією реальному процесу навантаження. Циклічне розрахункове значення характеризує «середній» режим навантаження і тому не повинно залежати від терміну служби об'єкта. У
ДБН циклічне розрахункове значення представлено в уніфікованій формі добутку характеристичного вертикального навантаження від одного крана i коефіцієнтів надійності $\gamma_{c \max }, \gamma_{c \min }$. Час дії циклічного навантаження враховується числом циклів (на добу) $n_{c}=270 \ldots 820$ в залежності від груп режимів роботи кранів

Квазіпостійне розрахункове значення вертикальної кранового навантаження, прийняте в розрахунках, яке враховує тривалі процеси в матеріалах конструкцій (повзучість й ін.), пропонується приймати рівним вертикальному навантаженню одного крана без вантажу (порожнього) $F_{01}^{\Pi} \quad 3$ введенням в формулу (17) коефіцієнта надійності $\gamma_{f p}=F_{01}^{\Pi} / F_{01}$

При розробці ДБН у частині горизонтальних кранових впливів були враховані основні положення, які стосуються фактичної природи і величин бічних сил мостових кранів. Для горизонтальних кранових навантажень в якості характеристичних значень були прийняті величини навантажень від двох кранів Н0 або одного крана Н01, що визначаються по-різному для чотириколісних і багатоколісних кранів.

Для чотириколісних кранів нормується бічна сила від одного крана, визначена за формулою (8), запропонованою А.В. Фігаровскім. Бічні сили Н01, обчислені за цією формулою, можуть бути прикладені:

- до коліс однієї сторони крана і спрямовані в різні боки (всередину або назовні розглядуваного прольоту будівлі), що відповідає обмеженню перекосу крана колесами одного боку;

- до коліс по діагоналі крана і також спрямовані в різні боки (всередину або назовні розглядуваного прольоту будівлі), що відповідає випадку обмеження перекосу крана колесами, розташованими по діагоналі крана.

При цьому до інших коліс прикладаються сили, рівні $0.1 F_{\max }^{n}\left(0.1 F_{\min }^{n}\right)$, спрямовані в найбільш невигідному напрямку (всередину або назовні розглядуваного прогону.

Для багатоколісних кранів введений новий норматив бічної сили на підставі результатів багаторічних випробувань таких кранів. Характеристичне значення бічної сили на колесо багатоколісних кранів 3 гнучким підвісом вантажу $H_{k}^{n}$ приймається рівним 0,1 від вертикального навантаження на колесо, підрахованого при розташуванні візка з вантажем, що дорівнює паспортній вантажопідйомності крана, посередині моста. 
Для багатоколісних кранів з жорстким підвісом вантажу $H_{k}^{n}$ приймається рівним 0,1 від максимального вертикального навантаження на колесо.

При визначенні характеристичних значень $H_{k}^{n}$ враховується, що бічні сили від двох багатоколісних кранів передаються на обидві сторони кранової колії. На кожній стороні крана бічні сили мають один напрямок - назовні або всередину прольоту, на різних коліях вони спрямовані в протилежні сторони (обидві всередину прольоту або обидві назовні). На одній із колій приймається повна бічна сила, на іншій колії приймається половина від бічної сили. На відміну від норм СНіП, наведені вище бічні сили мостових кранів пропонується враховувати при розрахунку міцності і стійкості балок кранових колій, рам, колон, фундаментів і основ.

Введене нормами ДБН допущення зниження вертикальних навантажень від кранів 3 постійними обмеженнями наближень візка базується на досить представницькому експериментальному і статистичному матеріалі [44] і дає можливість враховувати понижуючі коефіцієнти $K_{y}=0,94 \ldots 0,76$.

Даючи загальну оцінку українським нормам ДБН В.1.2-2006 «Навантаження і впливи» в частині кранового навантаження слід підкреслити, що вони складені на сучасній методичній основі, наближені до європейських норм Єврокод [40], базуються на представницькому статистичному матеріалі, більш диференційовані i мають наукове імовірнісне обгрунтування, глибше розроблене, ніж в нормах минулих років

Був проведений аналіз наслідків впровадження рекомендацій ДБН В.1.2-2:2006 «Навантаження і впливи» у частині навантажень мостових кранів [45]. Виявлено перевищення горизонтальних навантажень на колесо чотириколісних мостових кранів, визначених за ДБН, до 1,3 ..9,6 разів, порівняно із навантаженнями, розрахованими згідно зі СНiП. При переході до визначення силових впливів чотириколісних мостових кранів за ДБН згинальні моменти у колонах поперечних рамах одноповерхових виробничих будівель (ОВБ) від бічних сил зростають у 1,9...6,9 разів, порівняно із зусиллями від гальмівних сил за СНіП, та у $1,2 \ldots 7,8$ разів зростають згинальні моменти у конструкціях підкранових балок. Внаслідок цього виникає деяке зростання матеріалоємності підкранових балок, що в середньому становить $1,1 \%$, а також виявлене зростання до $24 \%$ матеріалоємності підкранових частин колон будівель, обладнаних чотириколісними кранами.

При дії на конструкції ОВБ багатоколісних мостових кранів навантаження на колесо багатоколісних кранів за ДБН перевищують навантаження за СНіП у 1,3 ..1,7 разів. Виявлено, що згинальні моменти у поперечних рамах при цьому зростають у $1,1 \ldots 1,2$ рази та до 1,6 разів у підкранових балках. На основі перевірок несучої здатності конструкцій ОВБ встановлено, що у випадку обладнання будівель багатоколісними мостовими кранами перехід до визначення навантажень за ДБН не призводить до збільшення витрат матеріалів конструкцій підкранових балок та колон.

Для нейтралізації наслідків упровадження у практику проектування норм рекомендовано застосовувати такий резерв сталевих каркасів ОВБ, як просторова робота каркасів. Встановлено, що урахування ефекту просторової роботи каркасів при розрахунку поперечних рам каркасів ОВБ на комбінації навантажень із урахуванням кранових навантажень за ДБН В.1.2-2:2006 дозволяє наблизити результати розрахунків рам на навантаження за СНiП 2.01.07-85 та уникнути додаткових витрат матеріалів.

Як видно 3 вищевикладеного, дослідження кранових навантажень на конструкції виробничих будівель має давню історію, і більшість робіт, виконаних $з$ даної тематики, спирається на результати натурних спостережень на ділянках виробничих будівель 3 найбільш інтенсивною роботою кранів. В окремих дослідженнях використовувалося також чисельне статистичне моделювання. Однак обчислювальні можливості того часу були обмеженими, і число випадкових випробувань в кожній задачі було відносно небагато. 3 огляду на ці обставини, А.В. Перельмутер виконав статистичне дослідження кранових навантажень, в якому були задіяні сучасні обчислювальні можливості [46] i методи математичного моделювання [47]. В результаті було наочно показано, що значення кранових навантажень і коефіцієнтів сполучень цих навантажень, представлені в нормах проектування, є дещо завищеними. Тому актуальним i реальним в теперішніх умовах є виконання досліджень, спрямованих на уточнення норм кранових навантажень, 3 використанням сучасних методів статистичного моделювання.

\section{Висновки}

Показано, що протягом останніх дев'яноста років вітчизняні норми проектування будівельних конструкцій в частині нормування кранових навантажень зазнали значних змін і розширили свої статистичні основи. Відзначається високий науковий рівень вітчизняних норм ДБН В.1.2-2006 «Навантаження i впливи», що мають сучасний статистичний базис, асоціюються 3 нормами Єврокод і забезпечують необхідний рівень надійності будівельних конструкцій. Розроблено і включено у ці норми модифікований облік бічних сил 
мостових кранів, розвинене обгрунтування нормативних (характеристичних) і розрахункових значень кранового навантаження. Для подальших досліджень виділяються такі завдання як подальший статистичний аналіз сполучень випадкових кранових навантажень, поглиблений розгляд фізичної природи кранових впливів, оцінювання впливу технологічного процесу на навантаження мостових кранів.

\section{Література}

1. Справочная книга для архитекторовъ, механиковъ и студентовъ («НÜТТЕ»). Часть I. - Шестое изданіе. - М. : Товарищество СКОРОПЕЧ. А.А. Левенсонъ, 1905. $1283 \mathrm{c}$.

2. Справочник инженера-проектировщика промсооружений. Том II. Расчетно-теооретический. - М.-Л. : Госстройиздат, 1934. - 709 c.

3. Балинский Б.С. Проектирование металлических конструкиий / Б.С. Балинский. - 2-е изд. - Харьков-Киев : ОНТИ НКПТ Государственное научно-техническое издательство Украины, 1935. - 433 с.

4. Кикин А.И. Теоретическое и экспериментальное исследование продольных крановых нагрузок / А.И. Кикин // Исследование действительной работы стальных конструкций промышленных зданий. - М. : ЦНИПС, 1938. - C. 127-156.

5. Романов Н.Е. Исследование поперечных горизонтальных крановых нагрузок кольцом / Н.Е. Романов // Исследование действительной работы стальных конструкичй промылиленных зданий / М. : ЦНИПС, 1938. - С. 164-175.

6. Стрелечкий Н.С. Об исчислении запасов прочности сооружений / Н.С. Стрелецикий // Металлические конструкции: Сборник трудов №1 МИСИ. - М.-Л.: Госстройиздат, 1938. - С. 3-32.

7. Барштейн М.Ф. Экспериментальное определение горизонтальных поперечных сил, возникающих при движении мостовых кранов прокатного цеха завода «Азовсталь» / М.Ф. Баритейн // Труды института ЦНИИПС. - М., 1951. - С. 16-51.

8. Балашов В.П. Поперечные силь при движении мостовых кранов с иентральным приводом механизма передвижения / В.П. Балашов // Сборник научных трудов ВНИИПТМАШ № 18. - М., 1957. - С. 24-59.

9. Хохарин А.Х. О боковых воздействиях мостовых кранов на каркас промышленного здания / А.Х. Хохарин // Промышленное строительство. - 1961. № 9. - C. 38-45.

10. Бать А.А. О расчете на выносливость / А.А. Бать // Строительная механика и расчет сооружений. - 1959. № 5. - C. 24-28.

11. Кикин А.И. Повымение долговечности конструкций промышленных зданий / А.И. Кикин, А.А. Васильев, Б.Н. Кошутин. - М.: Стройиздат, 1969. - 415 c.

12. Кикин А.И. Повышение долговечности конструкций промышленных зданий / А.И. Кикин, А.А. Васильев, Б.Н. Кошутин, Б.Ю. Уваров, Ю.Л. Вольберг. - 2-е изд. М.: Стройиздат, 1984. - 302 c.

13. Кочутин, Б.Н. Статистическое определение коэффиичентов перегрузки вертикальных крановых нагрузок / Б.Н. Кошутин // Металлические конструкиии (Работа школы Н.С. Стрелеикого). - М.: Стройиздат, 1966. C. 195-210.

14. Бать А.А. Статистическое изучение крановых нагрузок / А.А. Бать, Б.Н. Кошутин // Строительная механика и расчет сооружений. - 1960. - №2. - C. 1-5.

15. Клепиков Л.В. Определение нагрузок при расчете строительных конструкций / Л.В.Клепиков, В.А. Отставнов // Строительная механика и расчет сооружений. - 1962. - №5. - С. 39-45.

16. Кикин А.И. Изучение факторов, влияющих на величины боковых сил мостовых кранов в цехах металлургического завода / А.И. Кикин, И.В. Изосимов // Известия вузов. Строительство и архитектура. - 1966. - №12. - С. 1-8.

17. Изосимов И.В. Исследование силовых воздействий мостовых кранов / И.В. Изосимов, А.В. Фигаровский, С.Ф. Пичугин, В.Н. Валь // Металлические конструкиии (Работа школь профессора Н.С. Стрелецкого). - М.: Стройиздат, 1966. - С. 164-176.

18. Фигаровский А.В. Исследование боковых сил четырехколесных кранов с гибким подвесом груза / А.В. Фигаровский // Металлические конструкиии: Сборник трудов № 85. - М.: МИСИ, 1970. - С. 41-52.

19. Кикин А.И. Экспериментальные данные о поперечных горизонтальных силах от разливочных кранов / А.И. Кикин, А.В. Фигаровский, С.Ф.Пичугин // Промылиленное строительство. - 1967. - № 12. - С. 8-13. 20. Баритейн М.Ф. Статистический анализ боковых сил, возникающих при движении мостового крана / М.Ф. Баритейн, А.Н. Зубков // Строительная механика и расчет сооружений. - 1966. - № 2.

21. Кочутин Б.Н. О коэффициенте перегрузки боковых сил от мостовых кранов / Б.Н. Кошутин // Методика определения нагрузок на здания и сооружения: Сборник статей ЦНИИСК - М.: Госстройиздат, 1963. - С. 81-88. 22. Пичугин С.Ф. Результаты статистического экспериментального исследования горизонтальных и вертикальных нагрузок мостовых кранов на. конструкиии промышленных зданий / С.Ф. Пичугин // Исследование и расчет стр. конструкиий: Сборник научных трудов МГМИ, вып. 59. - Магнитогорск, 1970. - С. 8-16.

23. Пичугин С.Ф. $К$ исследованию крайних частей статистических распределений (на примере нагрузок мостовых кранов) / С.Ф. Пичугин // Проблемы надежности в строительном проектировании. - Свердловск, 1972. - C. 169-175.

24. Пичугин С.Ф. Результаты экспериментального изучения вертикальных нагрузок мостовых кранов на колонны мартеновских цехов / С.Ф. Пичугин, Ю.П. Леванин // Известия вузов. Строительство и архитектура. - 1974. №12. - C. 31-35.

25. Кунин Ю.С. Исследование статистических свойств режимов нагружения подкрановых конструкиий / Ю.С. Кунин, Ю.С. Эглескалн // Промышленное строительство. - 1969. - №9. - С. 36-39.

26. Валь В.Н. Влияние дефектов подкрановых путей на силовые воздействия мостовых кранов / В.Н. Валь, Ю.С. Эглескалн // Промышленное строительство. - 1969. - № 4. - C. 36-38.

27. Васильев А.А. Об уточнении расчетных вертикальных нагрузок от мостовых кранов / А.А. Васильев, Ю.С. Кунин, А.Т. Яковенко // Промышиленное строительство. - 1974. - № 6. - C. 31-33. 
28. Зданевич Ю.А. О некоторых резервах нагрузок на подкрановые конструкиии действующих сталеплавильных иехов / Ю.А. Зданевич // Труды ДИИТ, вып. 159. Днепропетровск, 1974.

29. Кошутин Б.Н. Исследование вертикальных и горизонтальных воздействий от мостовых кранов методом статистического моделирования / Б.Н.Кочутин, Ю.С. Кунин, С.А. Нищета // Облегченные конструкции покрытий зданий. - Ростов-на-Дону, 1979. - С. 195-199.

30. Бать А.А. О согласовании норм нагрузок для расчета кранов и подкрановых конструкций / А.А. Бать // Промышленное строительство. - 1969. - № 10. - С. 4647 (в порядке обсуждения).

31. Отставнов В.А. О новых дополнениях и изменениях главы СНиП ІІ-6-74 «Нагрузки и воздействия» / В.А. Отставнов, А.А. Бать, Л.В. Клепиков // Промьиленное строительство. - 1983. - № 9. - С. 9-10.

32. Кунин Ю.С. О нагрузках при расчёте жёсткости подкрановых балок / Ю.С. Кунин, Н.Я. Кузин // Промышленное строительство. - 1972. - № 6. - С. 26-27.

33. Плотников В.А. Исследование горизонтальных силовых воздействий от мостовых кранов / В.А. Плотников // Межвузовский сборник научных трудов. - Магнитогорск: МГМИ, 1990. - С. 122-125.

34. Кочутин Б.Н. Обобщенная математическая модель вертикальной крановой нагрузки / Б.Н. Кошутин, Ю.С. Кунин, В.А. Пашинский // Вопросы надежности железобетонных конструкиий. - Куйбымев, 1985. C. $40-51$.

35. Pichugin S. Analysis of Bridge Crane Loads on Industrial Buildings / S. Pichugin // XLIV Konferencja Naukowa KILiW PAN i KN PZITB. Tom VII. - Poznan-Krynica, 1998. - P. 171-178.

36. Пичугин С.Ф. Вероятностное представление нагрузок, действующих на строительные конструкиии / С.Ф. Пичугин // Известия вузов. Строительство. - 1995. № 4. - C. 12-18.

37. Пичугин С.Ф. Методика вычисления коэффициентов сочетаний нагрузок / С.Ф. Пичугин, В.А. Пашинский // Вопросы надежности железобетонных конструкиий. Куйбымев, 1982. - C. 94-97.

38. Пичугин С.Ф. Вероятностный расчет стальных элементов на совместное действие нагрузок / С.Ф. Пичугин // Известия вузов. Строительство - 1995. - № 5, 6. C. 23-29.

39. Pichugin S. Reliability Estimation of Steel Elements under Variable Loads // XLI Konferencia Naukowa KILIW PAN i KN PZITB «Krynica 1995». Tom 3. - Krakow-Krynica, 1995. P. 151-156.

40. Eurocode 1 EN 1991-3.: Actions on structures - Part 3: Actions induced by cranes and machinery. - Brussels: CEN, Sep. 2006. -42 p.

41. Пічугін С.Ф. Розрахункові коефіцієнти норм проектування на основі аналізу надійності сталевих конструкцій / С.Ф. Пічугін // Будівництво Украӥни. - 1994. - № 1. C. $18-20$.

42. Пічугін С.Ф. Кранові навантаження в ДБН В.1.22:2006 «Навантаження $i$ впливи» / С.Ф. Пічугін // Будівельні конструкції: Збірник наукових пращъ. - Вип. 67. Науково-технічні проблеми сучасного залізобетону. - К. : НДІБК, 2007. - С. 691-702.
43. Пашинський В.А. Циклічні розрахункові значення навантажень на будівельні конструкиії / В.А. Пашинський // Вибрации в технике и технологиях. - 1999. - № 2. C. 15-17.

44. Pichugin S. Probabilistic Description of Crane Load on Building Structures / S. Pichugin // XLIII Konferencja Naukowa KILiW PAN i KN PZITB. Tom III. - PoznanKrynica, 1997. - P. 171-178.

45. Sergiy Pichugin. Comparative Analysis of Loads from the Travelling Cranes of Different Producers / Pichugin Sergiy, Patenko Iulia, Maslova Svetlana // International Journal of Engineering \&Technology. Vol. 7, No 3.2 (2018). Pp. 36-39.

46. Perelmuter A.V. Statistical Simulation of Crane Loads and Calculated Force Combinations / A.V.Perelmuter // International Journal for Computational Civil and Structural Engineering. - 2017.-13 (2) - P. 136-144.

47. Pasternak H. Crane load modelling / H. Pasternak, B. Rozmarynowski, Y.-K. Wen // Structural Safety. Vol. 17. 1996.- P. 205-224.

\section{References}

1. Reference book for architects, mechanics and students ("HÜTTE") Part I (Sixth ed.). (1905). M.: SKOROPECH Partnership. A.A. Levenson, 1283 p.

2. Handbook of an engineer-designer of industrial structures. Volume II. Calculation and theoretical (1934). M.-L.: Gosstroyizdat, $709 \mathrm{p}$.

3. Balinsky, B.S. (1935). Design of metal structures (2nd ed). Kharkov-Kiev: ONTI NKPT State Scientific and Technical Publishing House of Ukraine, 433 p.

4. Kikin, A.I. (1938). Theoretical and experimental study of longitudinal crane loads. Research of the actual work of steel structures of industrial buildings, 127-154.

5. Romanov, N.E. (1938). Investigation of transverse horizontal crane loads by a ring. Research of the actual work of steel structures of industrial buildings, 164-175.

6. Streletsky, N.S. (1938). On the calculation of the safety margins of structures. Metal structures: Proceedings of MISI, $1,3-32$.

7. Barshtein, M.F. (1951). Experimental determination of horizontal shear forces arising from the movement of overhead cranes in the rolling shop of the Azovstal plant. Proceedings of the Institute TsNIIPS, 16-51.

8. Balashov, V.P. (1957). Cross forces during the movement of bridge cranes with a central drive of the movement mechanism. Collection of scientific works of VNIIPTMASH, 18, 24-59.

9. Khokharin, A.Kh. (1961). On the lateral loads of bridge cranes on the frame of an industrial building. Industrial construction, 9, 38-45.

10. Bat, A.A. (1959). On the calculation of endurance. Building mechanics and calculation of structures, 5, 24-28.

11. Kikin, A.I., Vasiliev, A.A., Koshutin, B.N. (1969). Increasing the durability of industrial buildings structures. M.: Stroyizdat, $415 \mathrm{p}$.

12. Kikin, A.I., Vasiliev, A.A., Koshutin, B.N., Uvarov, B. Yu., Volberg, Yu.L. (1984). Increasing the durability of industrial buildings (2nd ed.). M.: Stroyizdat, $302 \mathrm{p}$.

13. Koshutin, B.N. (1966). Statistical determination of the overload coefficients of vertical crane loads. Metal structures 
(Work of the school of N.S. Streletsky). M.: Stroyizdat, 195210

14. Bat, A.A., Koshutin, B.N. (1960). Statistical study of crane loads. Building mechanics and calculation of structures, $2,1-5$.

15. Klepikov, L.V., Otstavnov, V.A. (1962). Determination of loads in the calculation of building structures. Building mechanics and calculation of structures, 5, 39-45.

16. Kikin, A.I., Izosimov, I.V. (1966). Study of the factors affecting the magnitude of the lateral forces of overhead cranes in the shops of a metallurgical plant. Izvestiya vuzov. Construction and architecture, 12, 1-8.

17. Izosimov, I.V., Figarovsky A.V., Pichugin S.F., Val V.N. (1966). Investigation of the power effects of bridge cranes. Metal structures (Work of the school of NS Streletsky). M.: Stroyizdat, 164-176.

18. Figarovsky, A.V. (1970). Study of the lateral forces of four-wheel cranes with flexible load suspension. Metal structures: Collection of works of MISI, 85, 41-52.

19. Kikin, A.I.,. Figarovsky, A.V., Pichugin, S.F. (1967). Experimental data on transverse horizontal forces from casting cranes. Industrial construction, 12, 8-13.

20. Barshtein, M.F., Zubkov, A.N. (1966).Statistical analysis of lateral forces arising from the movement of an overhead crane. Building mechanics and calculation of structures, 2.

21. Koshutin, B.N. (1963). On the coefficient of overload of lateral forces from bridge cranes. Methodology for determining loads on buildings and structures: Collection of articles of TSNIISK, 81-88.

22. Pichugin, S.F. (1970). The results of a statistical experimental study of horizontal and vertical loads of overhead cranes on. structures of industrial buildings. Research and Calculation of Structural Structures: Collection of Scientific Papers of MGMI, 59, 8-16.

23. Pichugin, S.F. (1972). On the study of the extreme parts of statistical distributions (for example, the loads of overhead cranes). Problems of reliability in construction design, 169175.

24. Pichugin, S.F., Levanin, Yu.P. (1974). Results of experimental study of vertical loads of overhead cranes on columns of open-hearth shops. Izvestiya vuzov. Construction and architecture, 12, 31-35.

25. Kunin, Yu.S., Egleskaln, Yu.S. (1969). Study of the statistical properties of loading modes for crane structures. Industrial construction, 9, 36-39.

26. Val, V.N., Egleskaln Yu.S. (1969). The influence of crane runway defects on the power effects of bridge cranes. Industrial construction, 4, 36-38.

27. Vasiliev, A.A., Kunin, Yu.S., Yakovenko, A.T. (1974). On the clarification of the calculated vertical loads from bridge cranes. Industrial construction, 6, 31-33.

28. Zdanevich, Yu.A. (1974). On some reserves of loads on crane structures of operating steel-making shops. Proceedings of DIIT, 159.

29. Koshutin, B.N., Kunin, Yu.S., Nyscheta, S.A. (1979). Investigation of vertical and horizontal impacts from overhead cranes by the method of statistical modeling. Lightweight Building Coating Structures, 195-199.

30. Bat, A.A. (1969). About coordination of codes of loads for calculation of cranes and crane structures. Industrial construction, 10, 46-47 (in order of discussion).
31. Oststavnov, V.A., Bat, A.A., Klepikov, L.V. (1983). On new additions and changes to the chapter of SNiP II-6-74 "Loads and loadings". Industrial construction, 9, 9-10.

32. Kunin, Yu.S.. Kuzin N.Ya. (1972). About loads when calculating the rigidity of crane beams. Industrial construction, 6, 26-27.

33. Plotnikov, V.A. (1990). Investigation of horizontal force effects from bridge cranes. Interuniversity collection of scientific papers, 122-125.

34. Koshutin, B.N., Kunin, Yu.S., Pashinsky, V.A. (1985). Generalized mathematical model of vertical crane load, Questions of the reliability of reinforced concrete structures, $40-51$.

35. Pichugin, S. (1998). Analysis of bridge crane loads on industrial buildings. XLIV Konferencja Naukowa KILiW PAN i KN PZITB. Poznan-Krynica, Tom VII, 171-178.

36. Pichugin, S.F. (1995). Probabilistic representation of loads acting on building structures. Izvestiya vuzov. Construction, 4, 12-18.

37. Pichugin, S.F., Pashinsky, V.A. (1982). Methodology for calculating the coefficients of combinations of loads. Questions of the reliability of reinforced concrete structures, 94-97.

38. Pichugin, S.F. (1995). Probabilistic calculation of steel elements for joint action of loads. Izvestiya vuzov. Construction, 5, 6, 23-29.

39. Pichugin, S. (1995). Reliability estimation of steel elements under variable loads. XLI Konferencia Naukowa KILIW PAN i KN PZITB, Krakow-Krynica , Tom 3, 151156.

40. Eurocode 1 EN 1991-3.: Actions on structures - Part 3: Actions induced by cranes and machinery. (2006). Brussels: CEN, Sep..

41. Pichugin, S.F. (1994). Calculation coefficients of design codes based on the analysis of the reliability of steel structures. Construction of Ukraine, 1, 18-20.

42. Pichugin, S.F. (2007). Crane loads in DBN B.1.2-2: 2006 "Loads and iloadings". Building constructions: Collection of scientific works of NDIBK, 67, Scientific and technical problems of modern reinforced concrete, 691-702.

43. Pashinsky, V.A. (1999). Cyclic calculated values of loads on building structures. All-Ukrainian scientific and technical journal "Vibrations in technology and technology", 2, 15-17.

44. Pichugin, S. (1997). Probabilistic description of crane load on building structures. XLIII Konferencja Naukowa KILiW PAN i KN PZITB, Poznan-Krynica, Tom III, 171-178.

45. Pichugin, S., Patenko, Iu., Maslova S. (2018). Comparative analysis of loads from the travelling cranes of different producers. International Journal of Engineering \&Technology. 7 (3.2), 36-39.

46. Perelmuter, A.V. (2017). Statistical simulation of crane loads and calculated force combinations. International Journal for Computational Civil and Structural Engineering, 13(2), 136-144.

47. Pasternak, H., Rozmarynowski, B., Wen, Y.-K. (1996). Crane load modeling. Structural Safety, 17, 205-224.

Рецензент: д-р. техн. наук, професор О.В. Семко, Національний університет «Полтавська політехніка імені Юрія Кондратюка», Україна. 
Автор: ПІЧУГІН Сергій Федорович

доктор технічних наук, професор, професор

кафедри будівельних конструкцій

Національний університет «Полтавська

політехніка імені Юрія Кондратюка»

E-mail-pichugin.sf@gmail.com

ID ORCID: https://orcid.org/0000-0001-8505-2130

\title{
DEVELOPMENT OF RANKING OF CRANE LOADS ON BUILDING STRUCTURES
}

\author{
S. Pichugin
}

National University «Yuri Kondratyuk Poltava Polytechnic», Ukraine

Ensuring the reliability and safety of buildings and structures largely depends on a proper understanding of the nature and quantitative description and rationing of loads on building structures, including crane loads. Loads from cranes can be significant; they have a variable dynamic nature and have a significant force on the structure of industrial buildings. These features are to some extent reflected in the sections of design codes of building structures that contain standards for crane load. Most of the parameters of the crane load codes are probabilistic nature and require the use of statistical methods to substantiate them. These methods are constantly changing and evolving together with the regular revision of building design codes. Analysis of the evolution of domestic codes of crane load together with their statistical substantiation is an urgent task, which is the purpose of this article. The beginning of domestic standardization of crane loads was laid in 1930, when the "Uniform codes of construction design» were introduced. They separately normalized vertical, horizontal longitudinal and horizontal transverse crane loads. This division is preserved in all subsequent versions of the load codes from bridge and overhead cranes. Since the late 1930s, leading construction research institutes and universities have conducted research on crane loads, the results of which have been consistently incorporated into design codes. These studies are time consuming and complex, as they are performed in existing production facilities and require the development of specific methods and equipment for measuring loads from operating bridge cranes. For 90 years, load codes have been constantly changing, taking into account the experience of operation and trends in construction science. The 50 s of the last century were marked by the transition of structural calculations from the method of allowable stresses to the method of limit states, which led to a radical revision of the codes of crane loads. In the 60's and 80's, statistical studies of crane loads were intensified, the results of which opened up the possibility of reducing overload coefficients and introducing additional combination coefficients for crane loads. There were constant discussions about the assessment and consideration in the codes of horizontal transverse loads - braking and lateral forces from the skew of the moving cranes. This question still remains open for further research. It is also important to clarify the coefficients of load combination from several bridge cranes. With the collapse of the USSR, the new states had the opportunity to move away from the rough Soviet rationing and develop their own, more adequate codes for crane loads. Further development of crane codes in the CIS was realized in the form of national codes of individual states. Ukrainian specialists, in contrast to Russian standards developers, have prepared the State Standards of Ukraine DBN B.1.2: 2006 "Loads and impacts», conceptually different from SNiP in terms of crane loads. The publication of these codes was preceded by the systematization of the results of many years of work in the field of crane loads. Giving an overall assessment of Ukrainian standards of crane loads, it should be emphasized that they are compiled on a modern methodological basis, close to European standards Eurocode, based on representative statistics, more differentiated and have a scientific probabilistic rationale, more deeply developed than in codes of previous years.

Keywords: bridge cranes, overhead cranes, crane load, normative load, design load. 